\title{
CEPTEN SAĞLIK HARCAMASI YAPILMASINI BELİRLEYEN FAKTÖRLER: MİKRO VERİLER İLE TÜRKIYE ÖRNEĞİ
}

Esra DOĞAN ${ }^{1}$

\section{$\ddot{O} z$}

Sağlık hizmetlerine yönelik cepten harcamalar, hizmet niteliğinden bağımsız olarak yüksek gelir gruplarında ortaya çlkabilecek bir durumken, düşük gelir gruplarında da sosyal güvencenin yokluğuna bağlı olarak zorunlu olarak ortaya çıkabilmektedir. Hizmetin niteliğinden bağımsız olarak ortaya çıkan bu durum sadece fiyat farklılaşması temeline dayanmaktadır. Diğer taraftan sağlık hizmetlerinin niteliğindeki farklılaşmaya bağlı olarak cepten harcama yapılmasının tercih edilmesi halinde ise sağlık hizmetlerine yönelik cepten harcamalar hizmet farklılaşması temeline dayanmaktadır. Bu çalışmanın amacı da sağlık hizmeti için yapılan cepten harcamaların, sağlık hizmetlerindeki fiyat farklılaşması mı yoksa hizmet farklılaşmasına mı bağlı olarak gerçekleștiğini ortaya koymaktır. Bu doğrultuda hâlihazırda cepten sağlık harcaması yapanların sosyal güvenlik kapsamına dâhil olması halinde de cepten harcama yapma olasılığı üzerinde belirleyici olan faktörlerin saptanmasına yönelik lojistik regresyon analizi yapılmıştır. Yapılan analiz sonucu elde edilen bulgular, sosyal güvence kapsamındayken dahi cepten harcama yapılması üzerinde; sosyal güvencenin varlığı, gelir düzeyinin, genel sağlık durumunun, cinsiyet, medeni durum, yaş, öğrenim düzeyi, sağlik kurumu tercih nedeni değişkenlerinin belirleyici olduğu șeklindedir. Bu bulgulardan hareketle de cepten harcamaların sadece fiyat farklılaşmasına değil, hizmet farklılaşmasına bağlı olarak da ortaya çıktığı sonucuna ulaşılmıştır. Ulaşılan bu sonuç ise sağlık hizmetlerinin sosyal güvenlik kapsamındaki sunumunda niteliksel iyileşmelerin gerekliliğini ortaya koymuştur.

Anahtar Kelimeler: Cepten Sağhlk Harcaması, Fiyat Farklılaşması, Hizmet Farklılaşması, Lojistik Regresyon Analizi, Türkiye Sağlık Araştırması.

\footnotetext{
${ }^{1}$ Arş. Gör. Dr., Eskişehir Osmangazi Üniversitesi İktisadi ve İdari Bilimler Fakültesi, Maliye Bölümü, e-posta: edogan@ogu.edu.tr ORCID: 0000-0002-9886-4186
}

DOĞAN, E. (2020). Cepten Sağlık Harcaması Yapılmasını Belirleyen Faktörler: Mikro Veriler İle Türkiye Örneği. Sosyal Politika Çalışmaları Dergisi, 20(48) , 569-600. DOI: 10.21560/spcd.vi.552960 


\title{
DETERMINANTS OF OUT OF POCKET EXPENDITURES FOR HEALTH SERVICES: TURKEY SAMPLE VIA MICRO DATASET
}

\begin{abstract}
Out-of-pocket expenditures for health services, regardless of the service quality, may occur in high-income groups while in low-income groups it may be obligatory due to the absence of social security. This situation, which is independent of the quality of the service, is based only on price diversification. On the other hand, when it is preferred to make out-of-pocket spending depending on the difference of health services quality, out-of-pocket expenditures on health services are based on service diversification. The purpose of this study is to reveal that out-of-pocket expenses for health services are realized due to price diversification in health services or service diversification. In this respect, logistic regression analysis was conducted to determine the factors that determine the possibility of out-of-pocket expenditures in the context of the social security coverage of the out-of-pocket expenditures. The findings obtained from the analysis; the existence of social security, income level, general health status, gender, marital status, age, education level, health institution preference has an impact on out-ofpocket expenditures even when covered by social security. Based on these findings, it has been concluded that out of pocket expenditures are not only due to price diversification but also due to service diversification. This result revealed the necessity of qualitative improvements in the presentation of health services within the scope of social security.
\end{abstract}

KeyWords: Logistic Regression Analysis, Out-of-Pocket Payments, Price Diversification, Service Diversification, Turkey Health Investigation. 


\section{Giriș}

Dünya Sağlık Örgütü (DSÖ) Anayasasına göre sağlık "sadece hastalık ya da kusurun olmaması değil, fiziksel, zihinsel ve toplumsal refahın bütünüyle bulunması hali" olarak tanımlanmaktadır. DSÖ tarafından yapılan tanımlama her ne kadar doğrudan doğruya sağlık hizmetinin yararlanıcısı bağlamında ele alınmış olsa da, sağlık hizmetinden yararlanma, doğrudan ya da dolaylı olarak devlet dolayımıyla sağlanabilmektedir. Nitekim sağlık, 1982 Anayasasında Sosyal ve Ekonomik Haklar ve Ödevler başlığı altındaki 56. madde kapsamında "Herkes, sağlıklı ve dengeli bir çevrede yaşama hakkına sahiptir. Çevreyi geliştirmek, çevre sağlığını korumak ve çevre kirlenmesini önlemek Devletin ve vatandaşların ödevidir. Devlet, herkesin hayatını, beden ve ruh sağllğı içinde sürdürmesini sağlamak; insan ve madde gücünde tasarruf ve verimi artırarak, işbirliğini gerçekleştirmek amacıyla sağlık kuruluşlarını tek elden planlayıp hizmet vermesini düzenler. Devlet, bu görevini kamu ve özel kesimlerdeki sağlık ve sosyal kurumlarından yararlanarak, onları denetleyerek yerine getirir. Sağlık hizmetlerinin yaygın bir şekilde yerine getirilmesi için kanunla genel sağlık sigortası kurulabilir." şeklinde devlet ile ilişkili olarak ele alınmaktadır.

Sağlığın gerek doğrudan hizmet sunumunun gerçekleştirilmesi gerekse hizmet sunumunun denetim ve planlanmasının sağlanması noktasında devlet ile olan bağı, sağlık hizmetine teorik ve politik açıdan kamu hizmeti ve karma mal niteliğini kazandırmaktadır. Sağlık hizmetinin sahip olduğu karma mal niteliği, sağlık hizmetlerinin doğrudan doğruya kamu hizmeti olarak sunulan kısmının ötesinde özel mal şeklindeki talebini de mümkün kılmaktadır. Buna göre aynı tür ve kalitedeki sağlık hizmetinin kamu malı olarak talebi, kamu sağlık sigortası kapsamında ödenen sosyal güvenlik primleri ile karşılanırken; özel mal olarak talebi de katılım payı ve cepten ödeme şeklinde karşılanmaktadır. Bu durumda sağlık hizmetinin kamu ve özel mal olma hallerinin birbirinin alternatifi olduğu dolayısıyla da karma mal niteliğinin açığa çıktığı söylenebilir. Ancak sağlık hizmetinin, kamu ve özel mal olarak sunumunda hizmet niteliğinin farklılaşması dolayısıyla da hizmet farklılaşması olması halinde kamu ve özel mal olma halleri birbirinin alternatifi olma niteliğini kaybedecektir. Buna bağlı olarak da sağlık hizmetinin özel mal olarak talep edilmesi hali, kamu hizmeti olarak talep edilmesi halinin ikamesi olarak değil, 
tamamlayıcısı olarak ortaya çıkmaktadır. Bu durumda ise sosyal güvenlik kapsamında kamu malı olarak talep edilen hizmetin türü ya da kalitesinin yeterli olmaması halinde, katılım payı, özel sağlık sigortası veya cepten ödemeler karşllı̆̆ında özel mal şeklinde sağlık hizmet talebi ortaya çıkmaktadır.

DSÖ tarafından cepten ödemeler, bireylerin sağlık hizmetinden yararlandıkları anda sağlık hizmeti sunucularına doğrudan yaptıkları ödemeler olarak tanımlanmaktadır. Bu ödemeler, vergiler, özel sigorta primleri, katkı payları gibi sağlık hizmetleri için önceden yapılan ödemeleri ve ödemeyi yapana sonrasında ödemenin iadesi olanağı sunan sağlık harcaması finansman sistemlerini kapsamamaktadır. Bununla birlikte cepten ödemeler, DSÖ tarafından katastrofik ve yoksullaştırıcı etki ortaya çıkarma potansiyeli vurgulanarak, sağlık harcamalarına karşı finansal güvence sağlayan sağlık sistemi politikaları dâhilinde ele alınmaktadır. Buradan hareketle cepten ödemelerin DSÖ tarafından, sağlık hizmetinin özel mal şeklindeki talebinin kamu malı olarak sunumuna yönelmenin alternatifi değil; aksine tamamlayıcısı olması nedeniyle zorunlu bir yönelimi gerektirdiği şeklinde değerlendirildiği söylenebilir.

Türkiye İstatistik Kurumu (TÜİK) tarafından yayınlanan Türkiye’deki sağlık harcama istatistiklerine bakıldığında da 2017 itibariyle sağlık harcamalarının \%78'nin genel devlet bütçesinden karşılanırken, \%17,1'lik kısmının da hanehalkı tarafından cepten ödeme şeklinde karşılandığı görülmektedir. Bu çalışma kapsamında da sağlık hizmeti için yapılan cepten harcamaların, sağlık hizmetlerindeki fiyat farklılaşması mı yoksa hizmet farklılaşmasına mı bağlı olarak gerçekleştiğini ortaya koymak amaçlanmıştır. Buna yönelik öncelikle literatürde yer alan çalışmalar incelenmiş, sonrasında ise halihazırda cepten sağlık harcaması yapanların sosyal güvenlik sigortası kapsamındayken de cepten harcama yapmaya devam etme olasılıklarını ortaya koyabilmek amacıyla lojistik regresyon analizini içeren ampirik bir değerlendirme yapılmıştır.

\section{Literatür İncelemesi}

Cepten sağlık harcamalarına yönelik literatürde yer alan çalışmalar incelendiğinde, söz konusu harcamalar üzerinde etkili olan faktörlerin ortaya konulması amacıyla yapılan istatistiki analizlerden oluştuğu görülmüştür. Bununla birlikte literatürdeki çalışmalarda, genel anlamıyla cepten sağlık 
harcamalarının belirleyenleri ve cepten yapılan sağlık harcamaların hane halkı üzerindeki yoksullaştırıcı etkisine karşılık gelen katastrofik sağlık harcamalarının belirleyenleri olmak üzere iki farklı bağlam bulunmaktadır. Doğrudan doğruya cepten yapılan sağlık harcamalarının ele alındığı çalışmalarda, bu harcamaların ortaya çıkma olasılığını etkileyen faktörlerin belirlenmesi amaçlanmıştır. Katastrofik sağlık harcamalarına yönelik çalışmalardaki amaç ise, cepten yapılan sağlık harcamaları üzerinde belirleyici olan faktörlerin ötesinde, yapıldığı takdirde hanehalkı üzerinde yoksullaştırıcı etkiye yol açan sağlık harcamalarının ortaya çıkma olasılığını etkileyen faktörlerin belirlenmesidir. Bu amaçlar doğrultusunda her iki bağlamda da geniş bir örneklemi kapsayan ülke ölçeğindeki hane halkı istatistiklerinden hareketle ikili ya da çoklu lojistik regresyon analizlerinden yararlanılmıştır.

Farklı ülke örnekleri ve Türkiye'de yapılan çalışmalarda, katastrofik sağlık harcamaları üzerinde belirleyici olan faktörler yaş, cinsiyet, medeni durum, gelir (harcama) düzeyi, hane halkı büyüklüğü, öğrenim düzeyi, sosyal güvencenin varlığı, kronik rahatsızlık bulunması, yaşam faaliyetlerini kısıtlayıcı durumun varlığı ve yaşanılan bölge şeklindedir. Cepten yapılan sağlık harcamaları üzerinde etkili olan faktörler ise katastrofik sağlık harcamaları üzerinde belirleyici olan faktörlerin tamamı ve bunlara ilave olarak din, sağlık hizmetlerine yönelik özel tercihlerdir. Ancak gerek doğrudan doğruya cepten yapılan sağlık harcamalarında gerekse katastrofik harcamalarda etkili olan faktörlerin, söz konusu harcamaları hangi yönde etkilediği çalışmaların yapıldığı ülkeler ya da bölgeler bazında farklılık göstermektedir. Bu doğrultuda her bir faktöre ilişkin bulgular aşağıda yer almaktadır.

- Yaş faktörünün birçok ülkede gerek cepten yapılan sağlık harcamaları gerekse katastrofik sağlık harcamaları üzerinde belirleyici olduğuna sonucuna ulaşılmıştır. Buna göre cepten yapılan sağlık harcamalarının Avusturya (Sanwald ve Theur, 2015 ve 2016), Burkina Faso (Mugisha, vd., 2002), Amerika Birleşik Devletleri (Goldman ve Zissimopoulos, 2003), Çin (You ve Kobayashi, 2011) için yapılan çalışmalarda; katastrofik sağlık harcamalarının ise düşük ve orta gelir grubundaki ülkelerde, Senegal (Sene ve Cisse, 2015), İspanya (Rubio, vd., 2019), Tanzanya (Brinda, vd., 2014) ve Kolombiya (Lara, 2016) için yapılan çalışmalarda özellikle 65 yaş ve üstü 
olmakla birlikte yaştaki artış nedeniyle arttığı sonucuna ulaşılmıştır. Türkiye için yapılan çalışmalarda da özellikle hanede 65 yaş ve üstü yaşlılar ile 5 yaş altındaki çocukların bulunması halinde cepten sağlı harcamalarının (Yıldırım, vd., 2011) ve katastrofik sağlık harcamalarının (Yereli, vd., 2014; Tokatlığlu ve Tokatlığlu 2018; Yardım, vd., 2010; Erus ve Aktakke, 2012) arttığ 1 sonucuna ulaşılmıştır.

- Cinsiyet faktörünün, az sayıda ülkede belirleyici olduğu sonucuna ulaşılmış olup bu sonuçlar da ilgili ülkeler arasında farklılık göstermektedir. Buna göre Burkina Faso (Mugisha, vd., 2002) ve Bangladeş'te (Mamun, vd., 2018) erkekler kadınlara göre daha çok cepten harcama yaparken, Fildişi Sahillerinde (Attia-Konan, vd., 2019) kadınların erkeklere göre daha fazla cepten sağlık harcaması yaptığı sonucuna ulaşılmıştır. Tanzanya (Brinda, vd., 2014) ise katastrofik sağlık harcamaları üzerinde cinsiyetin belirleyici olduğu tek çalışma olup, burada da kadınların erkeklere göre daha fazla katastrofik nitelikte harcama yaptığı ortaya konulmuştur. Türkiye için yapılan çalışmalara göre de kadınların erkeklere göre cepten harcama (Başara ve Şahin, 2008) ve katastrofik harcama (Tokatlıŏlu ve Tokatlıŏlu, 2018) yapma olasılığı daha yüksektir.

- Medeni durum, sadece iki çalışmada etkili faktör olarak belirlenmiştir. Fildişi sahilleri çalışmasında (Attia-Konan, vd., 2019) evlilerin bekârlara göre daha fazla cepten sağlık harcaması yaptığı; İspanya için yapılan çalışmada (Rubio, vd., 2019) ise bekârların evlilere göre daha fazla katastrofik nitelikte harcama yapığı sonucuna ulaşılmıştır. Türkiye için yapılan çalışmalara göre evlilerin bekârlara göre cepten harcama (Başara ve Şahin, 2008) ve katastrofik harcama (Yereli, vd., 2014; Tokatlığlu ve Tokatlığlu, 2018) yapma olasılığı daha yüksektir.

- Hane halkı gelir düzeyi, cepten yapılan sağlık harcamalarında bir faktör olarak ele alınırken, katastrofik sağlık harcamalarında gelir düzeyi yerine harcama düzeyi faktörü kullanılmıştır. Buna göre Demokratik Kongo Cumhuriyeti (Laokri, vd., 2018), Amerika Birleşik Devletleri (Goldman ve Zissimopoulos, 2003), Bangladeş (Mamun, vd., 2018), Çin (You ve Kobayashi, 2011), Avusturya (Sanwald ve Theurl, 2016) ve Fildişi Sahilleri (Attia-Konan, vd., 2019) için yapılan çalışmalarda gelir düzeyi yükseldikçe 
cepten yapılan sağlık harcamalarının da yükseldiği sonucuna ulaşılmıştır. Düşük ve orta gelir seviyesindeki ülkeler (Bernabe, vd., 2017), İspanya (Rubio, vd., 2019), Hindistan (Sangar, vd., 2019) ve Kolombiya'da (Lara, 2016) ise hane halkının gelir (harcama) düzeyi düştükçe katastrofik nitelikte harcamaların ortaya çıkma olasılığı artmaktadır. Türkiye için yapılan çalışmalara göre gelir düzeyi yükseldikçe cepten harcama yapma olasılığı yükselirken (Başara ve Şahin, 2008; Erus ve Aktakke, 2012), katastrofik harcama yapma olasılığı azalmaktadır (Yereli, vd., 2014; Tokatlığlu ve Tokatlığlu, 2018; Çınaroğlu 2018).

- Hanede bulunan kişi sayısı arttıkça, Demokratik Kongo Cumhuriyeti (Laokri, vd., 2018), Bangladeş (Mamun, vd., 2018) ve Fildişi Sahilleri'nde (Attia-Konan, vd., 2019) cepten yapılan sağlık harcamaları; Tanzanya (Brinda, vd., 2014) ve Kolombiya'da (Lara, 2016) ise katastrofik nitelikteki sağlık harcamaları artmaktadır. Ancak hanede bulunan kişi sayısındaki artış Hindistan'da (Sangar, vd., 2019) katastrofik nitelikteki sağlık harcamalarının azalmasına yol açmaktadır. Türkiye için yapılan çalışmalara göre hanede bulunan kişi sayısındaki artış cepten harcama yapma (Başara ve Şahin 2008) ve katastrofik harcama yapma olasılığını azaltmaktadır (Yereli, Köktaş ve Selçuk 2014; Tokatlığlu ve Tokatlığlu 2018). Ancak farklı bir çalışmada da hanede bulunan kişi sayısındaki artışın cepten harcama yapma olasılığını arttırdığı sonucuna ulaşılmıştır (Erus ve Aktakke, 2012).

- Öğrenim düzeyi arttıkça cepten yapılan sağlık harcamaları Çin (You ve Kobayashi, 2011) ve Avusturya'da (Sanwald ve Theurl, 2016) artarken, Bangladeş'te (Mamun, vd., 2018) azalmaktadır. Katastrofik sağlık harcamaları ise düşük ve orta gelir grubundaki ülkeler (Bernabe, vd., 2017) ile İspanya'da (Rubio, vd., 2019) öğrenim düzeyindeki artışla azalırken, Tanzanya'da (Brinda, vd., 2014) öğrenim düzeyindeki artışla artmaktadır. Türkiye için yapılan çalışmalara göre öğrenim düzeyindeki artış cepten harcama yapma olasılığını arttırırken (Başara ve Şahin, 2008) katastrofik harcama yapma olasılığını azaltmaktadır (Yereli, vd., 2014; Tokatlığlu ve Tokatlığlu, 2018).

- Diğer faktörlere göre sosyal güvence faktörü, belirleyici bir etkiye sahip olup; bütün çalışmalarda sosyal güvencenin varlığı harcama düzeyini 
azaltmaktadır. Buna göre sosyal güvencenin varlığı, Hindistan (Bose ve Dutta, 2018), Çin (You ve Kobayashi, 2011) ve Fildişi sahillerinde (AttiaKonan, vd., 2019) cepten yapılan sağlık harcamalarını azaltırken, düşük ve orta gelir grubundaki ülkeler (Bernabe vd., 2017), Senegal (Sene ve Cisse, 2015) ve Kolombiyada (Lara, 2016) katastrofik nitelikteki sağlık harcamalarını azaltmaktadır. Bununla birlikte özel sağlık sigortası yerine kamu sağlık sigortasının bulunması halinde Avusturya'da (Sanwald ve Theurl, 2016) cepten, Hindistan'da (Sangar, vd., 2019) ise katastrofik nitelikteki sağlık harcamaları azalmaktadır. Türkiye için yapılan çalışmalara göre herhangi (özel ya da kamu) sağlık sigortasının bulunması cepten harcama yapma olasılığını arttırırken (Başara ve Şahin, 2008), katastrofik harcama yapma olasılığını azaltmaktadır (Yardım, vd., 2010; Yereli, vd., 2014; Tokatlığlu ve Tokatlığlu, 2018).

- Kronik rahatsızlığın bulunmasının, az sayıda ülkede belirleyici olduğu sonucuna ulaşılmıştır. Buna göre kronik rahatsızlığın, Çin (You ve Kobayashi, 2011) ve Amerika Birleşik Devletleri’nde yapılan iki çalışmada (Paez, vd., 2009; Hwang, vd., 2001) cepten yapılan sağlık harcamalarını; İspanyada (Rubio, vd., 2019) ise katastrofik nitelikteki sağlık harcamalarını arttırdığ 1 sonucuna ulaşılmıştır. Türkiye için yapılan çalışmalara göre kronik rahatsızlığın bulunması halinde cepten harcama yapma olasılığı yükselmektedir (Başara ve Şahin, 2008).

- Yaşam faaliyetlerini kısıtlayıcı bir rahatsızlı̆̆ın bulunması sadece iki çalışmada etkili faktör olarak belirlenmiştir. Demokratik Kongo Cumhuriyeti çalışmasında (Laokri, vd., 2018) cepten yapılan sağlık harcamalarını, Tanzanya çalışmasında (Brinda, vd., 2014) ise katastrofik nitelikteki sağlık harcamalarını arttırdığı sonucuna ulaşılmıştır. Türkiye için yapılan çalışmalara göre engellilik halinin bulunması durumunda katastrofik nitelikteki sağlık harcaması yapma olasılı̆̆ının yükselmektedir (Yardım, vd., 2010; Yereli, vd., 2014; Tokatlığlu ve Tokatlığlu, 2018).

- Yaşanılan bölge, cepten yapılan sağlı harcamaları için Burkina Faso (Mugisha, vd., 2002) ve Çin'de (You ve Kobayashi, 2011); katastrofik sağlık harcamaları için ise düşük ve orta gelir grubundaki ülkeler (Bernabe, vd., 2017) ve İspanya (Rubio, vd., 2019) için belirleyici faktör niteliğindedir. 
Buna göre kentte yaşayanlar kırsalda yaşayanlara göre daha çok cepten sağlık harcaması yaparken (Mugisha, vd., 2002), kırsalda yaşayanlar da kentte yaşayanlara göre daha çok katastrofik sağlık harcaması yapmaktadır (Bernabe, vd., 2017). Türkiye için yapılan çalışmalara göre kente göre kırsalda cepten harcama yapma (Başara ve Şahin, 2008) ve katastrofik harcama yapma olasılığı daha yüksektir (Yardım, vd., 2010; Yereli, vd., 2014; Tokatlığlu ve Tokatlığlu, 2018).

- Dinin sadece Hindistan'da (Sangar, vd., 2019) katastrofik sağlik harcamaları üzerinde etkili bir faktör olduğu sonucuna ulaşılmıştır. Buna göre Hindistan'daki Müslümanlar ve diğer azınlıktakiler Hinduizm inancındakilere göre daha çok katastrofik sağlık harcaması yapmaktadır. Türkiye için yapılan çalışmalarda din faktörü incelemelere dâhil edilmemiştir.

- Katastrofik harcamalar üzerinde belirleyici olmayan ancak cepten harcamalar üzerinde belirleyici olan sağlık hizmetine yönelik özel tercihler sadece bir ülkede etkili faktör olarak bulunmuştur. Buna göre özel sağllk hizmeti tercihinin Bangladeş’te (Mamun, vd., 2018) cepten sağlık harcamaları üzerinde belirleyici olduğu sonucuna ulaşılmıştır. Türkiye için de, Ankara'daki hastaneler için yapılan bir çalışmada, sağlık hizmetinin niteliğinin cepten sağlık harcaması yapılma olasılığını yükselttiği sonucuna ulaşılmıştır (Yıldırım vd., 2011).

Buçerçevedeliteratürdeyeralançalışmalarbütünolarakdeğerlendirildiğinde; yapılan analizlerin doğrudan doğruya cepten harcamalar üzerinde etkili olan faktörlerin ortaya konulmasını amaçladığı ve yapılan analizler sonucu elde edilen bulguların Türkiye ölçeğinde ulaşılan sonuçların diğer ülkelerdeki sonuçlar ile benzerlik gösterdiği görülmektedir. Bu doğrultuda 65 yaş ve üzeri yaşlılar ile 5 yaş altı çocuğun bulunduğu hane halkının, kadınların, evli olanların, öğrenim düzeyi yüksek olanların, sağlık sigortası kapsamında yer alanların, kronik rahatsızlığı bulunanların cepten sağlık harcaması yapma olasılığının daha yüksek olduğu söylenebilir. 


\section{Ampirik Değerlendirme}

$\mathrm{Bu}$ bölümde, literatürde yapılan bilimsel çalışmalar da göz önünde bulundurularak, halihazırda cepten sağlık harcaması yapanların sosyal güvenlik sigortası kapsamındayken de cepten harcama yapmaya devam etme olasılıklarını ortaya koyabilmek amacıyla lojistik regresyon analizini içeren ampirik bir değerlendirme yapılmıştır. Bu doğrultuda öncelikle araştırmanın kapsamı ve bu kapsam dahilinde uygulanan yöntem hakkında bilgi verilecek, sonrasında ise elde edilen bulgular ortaya konularak bir değerlendirme yapilacaktır.

\section{Araştırmanın Amacı ve Kapsamı}

Araştırmanın amacı Türkiye'de hâlihazırda cepten sağlık harcaması yapanların sosyal güvenlik kapsamındayken de cepten harcama yapma olasılığ üzerinde etkili olan faktörlerin ortaya konulmasıdır. Bu amaç doğrultusunda TÜİK Sağlık İstatistikleri 2016 mikro veri setinden yararlanılmıştır.

TÜİK mikro veri setine ilişkin anket formu toplam 444 adet sorudan ve dört bölümden oluşmaktadır. İlk bölüm genel nitelikli demografik ve sosyoekonomik özelliklerine, ikinci bölüm 0-6 yaş grubu, üçüncü bölüm 7-14 yaş grubu, dördüncü bölüm ise 15 yaş ve üzeri grubunun sağlık durumlarına ilişkin sorulardan oluşmaktadır. Araştırmanın kapsamı doğrultusunda anket formundaki ilk ve dördüncü bölümde yer alan toplam 194 soru esas alınmıştır. Söz konusu sorulardan ise çalışmanın amacı ile doğrudan doğruya uyumlu olan 32 soru analiz kapsamında yer almıştır ${ }^{21}$.

Mikro veri seti toplam 23.606 kişiye ilişkin verileri içermektedir. Ancak araştırmanın ana kütlesinin cepten sağlık harcaması yapan ve Türkiyede ikamet eden 15 yaş üstü bireyleri oluşturması nedeniyle toplam 2.556 kişiye ilişkin veriden yararlanılmıştır.

\section{Yöntem}

Araştırmanın amacı doğrultusunda kapsam dâhilinde yer alan veriler SPSS 16 programında işlenerek analiz edilmiştir. Analiz sürecinde öncelikle

\footnotetext{
${ }^{2}$ Analiz kapsamındaki soruların yer aldığı değişken listesi: http://www.tuik.gov.tr/MicroVeri/ sagAr 2016/turkce/downloads/2016 deggisskenacciiklamasii.pdf
} 
ankete katılanların sosyoekonomik düzeylerini görebilmek için frekans analizi yapılmıştır. Daha sonra ilgili değişkenler arasındaki ilişkilerin ortaya konulabilmesi amacıyla çapraz tablolar oluşturulmuştur. Analiz sürecinin devam eden aşamasında ise sosyal güvenlik kurumu kapsamında sağlık güvencesine sahip olanların cepten sağlık harcaması yapma olasılı̆̆ının ortaya konulması amacıyla örneklem büyüklüğü de göz önünde bulundurularak lojistik regresyon analizi yapılmıştır.

Lojistik regresyon analizi ile bağımlı ve bağımsız değişkenler arasındaki ilişkinin, en az değişken ile en iyi uyuma sahip olacak şekilde tanımlanarak kabul edilebilir bir model kurulması sağlanmaktadır (Atasoy, 2001). Lojistik regresyon analizinde bağımlı değişken kategorik olup, bu analiz ile bağımlı ve bağımsız değişkenler arasındaki ilişkinin ötesinde bağımlı değişkenin değerinin tahmin edilmesi amaçlanmaktadır. Buna bağlı olarak da bağımlı ve bağımsız değişken arasındaki matematiksel bağıntının incelendiği analizlerin (doğrusal regresyon analizi, diskriminant analizi) gerektirdiği değişkenlerin normal dağılımı, doğrusallık, varyans-kovaryans matrislerinin eşitliği gibi koşullardan bağımsızdır (Çokluk, 2010). Söz konusu koşullardan bağımsızlığın sağladığı esneklik lojistik regresyon analizini diğer regresyon analizlerine göre daha avantajlı hale getirmekle birlikte, bu analizin yapılabilmesi üç temel aşamada gerçekleşmektedir. İlk olarak lojistik regresyon analizine uygun modelin oluşturulması, ikinci olarak bu modeldeki değişkenler arası çoklu doğrusal bağlantının bulunup bulunmadığının saptanması gerekmektedir. Uygun model seçimi ve modeldeki değişkenler arasında çoklu doğrusal bağlantının olmadığının ortaya konulması halinde son aşama olan lojistik regresyon analizi gerçekleştirilebilmektedir. Her bir aşamaya ilişkin yöntemsel detaylar aşağıda yer almaktadır.

- Lojistik regresyon analizinde bağımlı değişkenin tahmini, bir durumun diğer duruma ya da durumlara göre gerçekleşme olasılığının gerçekleşmeme olasılığına oranlanmasıyla (odds ratio) yapılmaktadır. Söz konusu oranın doğal logaritması alınarak oluşturulan lojistik regresyon modelinin parametrelerinin seçiminde ise kullanılan standart ve adımsal iki temel yöntem; adımsal yöntemin kendi içinde de ileriye ve geriye doğru olmak üzere iki alt yöntem bulunmaktadır. Standart yöntem, teoriye dayanan belirlenmiş bir modelin testine yönelikken; adımsal yöntem, 
değişkenlerin modele tek tek ilave edilmesiyle ya da elenmesi ile uygun modelin oluşturulmasına yöneliktir. Buna göre ileriye doğru yöntemde modele ilk olarak sabit terim sonrasında ise diğer değişkenler tek tek eklenirken; geriye doğru yöntemde tüm bağımsız değişkenler modelde yer alır sonrasında modelin iyileşmesine en az katkı sağlayan değişkenden başlanarak eleme yapılmaktadır. Hem ileriye hem de geriye doğru adımsal yöntemde her bir adımda analiz dışı bırakılması gereken değişken olup olmadığı incelenmekte olup, bu inceleme "Olabilirlik Oran İstatistiği", "Durum İndeksi” ve "Wald İstatistiği” kullanılarak gerçekleştirilmektedir (Çokluk, 2010). Buna göre "Olabilirlik Oran İstatistiği” yönteminde mevcut model ile bağımsız değişkenin dışarıda bırakıldığı model karşılaştırılarak model uyumundaki değişmeye bakılmaktadır. İlgili değişkenin modelden çıkarılması (modele eklenmesi) model uyumunda iyileşmeye neden oluyorsa bu değişkenin içerilmediği (içerildiği) model tercih edilir. "Wald İstatistiği” yönteminde ise her bir bağımsız değişken için lojistik regresyon katsayısının anlamlılı̆̆ test edilmekte olup; "herhangi bir logit katsayısının sıfıra eşit olduğu” şeklindeki boş hipotezin kabul edildiği (reddedildiği) durumlarda ilgili değişkenin modelden çıkartılması (modele eklenmesi) esasına dayanmaktadır.

- Çoklu doğrusal bağlantı, modelde yer alan bağımsız değişkenler arasında ilişki olması halinde ortaya çıkmaktadır. Bu durumda testin gücü önemli ölçüde düşmekte, I. Tip hata olasılığı bulunmasa bile II. Tip hata olasılığı yükselmektedir. Buna bağlı olarak da modeldeki katsayılar ve standart hatalar gözlemlerdeki birkaç değişikliğe bile duyarlı hale gelmektedir (Garson, 2012, s. 45) Çoklu doğrusal bağlantının tespiti, bir taraftan öz değerlerin, durum indeksinin ve varyans oranlarının yer aldığı çoklu doğrusal bağlantı teşhis tablosu ile sağlanırken; bir taraftan da tolerans ve varyans artış faktörleri de incelenerek sağlanabilmektedir. Buna göre i) herhangi bir değişkene ilişkin özdeğerin diğerlerinden çok büyük olması ya da durum indeksi diğerlerinden çok büyük bir değerin bulunması halinde; ii) farklı değişkenlerin en yüksek varyansının aynı özdeğere yüklenmesi halinde; iii) Tolerans değerinin 0,1'den küçük olması halinde; iv) Varyans artış faktörünün (Variance Inflation Factor-VIF) 10'dan büyük olması halinde çoklu doğrusal bağlantı bulunmaktadır (Field, 2005). 
- Lojistik regresyon analizinde sınıflandırma, başlangıç modeli, başlangıç modelinde yer almayan değişkenlerin anlamlılı̆̆ı, model katsayılarının anlamlılı̆̆ı, modelin uyum iyiliği, model değişkenlerinin tahmin sonuçlarına ilişkin aşamaları içeren testler bulunmaktadır. Bu testlerde sırasıyla bağımlı değişkenin kategorileri bağlamında sınıflandırma yapılmakta, sonrasında ilk olarak modelde yer alması gereken değişkenlerin belirlenmesi amacıyla anlamlılık testleri yapılmakta, sonrasında ise modelde yer alan katsayıların Omnibus Testi ile anlamlılığı test edilmektedir. Modelde yer alması gereken değişkenlerin saptanmasını takiben bu değişkenlerin bağımlı değişkenin varyansı üzerindeki etkisi Cox \& Snell ve Nagelkerke değerleri ile ölçülmekte ve devamında yapılan Hosmer ve Lemeshow Testi ile de lojistik regresyon modelinin bütün olarak uyumu değerlendirilmektedir. Modelin uyum iyiliğinin ortaya konulmasını takiben oluşturulan modelin tahmin sonuçları değerlendirilmektedir.

$\mathrm{Bu}$ çerçevede bu çalışma kapsamında Türkiye'de hâlihazırda cepten sağlık harcaması yapanların sosyal güvenlik kapsamındayken de cepten harcama yapılması olasılı̆̆ üzerinde belirleyici olan faktörlerin ortaya konulabilmesi ve bu amaç doğrultusunda incelenen örneklemin büyüklüğü nedeniyle ikili (binary) lojistik regresyon analizi yapılmıştır. Lojistik regresyon analizi kapsamında kullanılan yöntemler ise i) Çalışmanın amacının, teoriye dayanan hazır bir modelin testi yerine, değişkenlerin eklenme/elenme yöntemi ile uygun modelin oluşturulması esasına dayanması nedeniyle adımsal lojistik regresyon yöntemi; ii) Her ne kadar örneklem büyüklügünün fazla olması halinde Wald İstatistiği tercih edilse de, bu istatistiğinin her zaman güvenilir sonuçlar vermemesi nedeniyle olabilirlik oran istatistiği yöntemi; iii) Modelin oluşturulmasında, bir bağımsız değişkenin etkisi sabi tutulurken diğer bağımsız değişkenin anlamlı etkiye sahip olması anlamına gelen baskılama etkisinin ortaya çıkmaması için ve analiz kapsamındaki değişken sayısının fazla olması nedeniyle değişken eleme yöntemi (geriye doğru) şeklindedir.

\section{Araştırmanın Bulguları}

Araştırmanın kapsam, amaç ve yöntemi dahilinde elde edilen bulgular, öncelikle frekans analizi ve çapraz tablo teknikleri kullanılarak kapsam 
dahilindeki örneklemin yapısının ortaya koyulması, sonrasında ise uygulanan lojistik regresyon analizi süreç ve sonuçlarının özetlenerek değerlendirilmesi şeklinde iki aşamada sunulmaktadır.

Örneklemin Sosyoekonomik Özelliklerine İlişkin Analiz Sonuçları

Örneklemin sosyoekonomik özelliklerinin ortaya koyulabilmesi amacıyla öncelikle frekans analizi sonuç ve değerlendirmelerine yer verilmektedir. Frekans analizinden elde edilen sonuçlardan hareketle gerekli görülen değişkenler için de çapraz tablo tekniği uygulanarak elde edilen sonuçlar değerlendirilmektedir.

Tablo 1: Demografik Değişkenler için Frekans Analizi Sonuçları

\begin{tabular}{|c|c|c|c|c|c|c|c|c|c|}
\hline \multicolumn{10}{|c|}{ KATEGORILER } \\
\hline \multirow{3}{*}{$\begin{array}{c}\text { Sağlık } \\
\text { Kurum } \\
\text { Tercih } \\
\text { Nedeni }\end{array}$} & & $\begin{array}{c}\text { Sosyal } \\
\text { Güvence }\end{array}$ & Yakınlık & $\begin{array}{c}\text { Daha iyi } \\
\text { Sağlık } \\
\text { Hizmeti }\end{array}$ & $\begin{array}{c}\text { Başka } \\
\text { Seçeneğin } \\
\text { Olmaması }\end{array}$ & Güvenilirlik & Ucuzluk & Diğer & Toplam \\
\hline & Sıklık & 953 & 594 & 253 & 212 & 150 & 147 & 247 & 2556 \\
\hline & $\begin{array}{c}\text { Yüzde } \\
(\%)\end{array}$ & 37,3 & 23,2 & 9,9 & 8,3 & 5,9 & 5,8 & 9,6 & 100 \\
\hline \multirow{3}{*}{ Yaş } & & $15-24$ & 25-34 & $35-44$ & 45-54 & 55-64 & 65-74 & $75+$ & Toplam \\
\hline & Siklık & 376 & 510 & 578 & 447 & 335 & 192 & 118 & 2556 \\
\hline & $\begin{array}{l}\text { Yüzde } \\
(\%)\end{array}$ & 14,71 & 19,95 & 22,61 & 17,49 & 13,11 & 7,51 & 4,62 & 100 \\
\hline \multirow{3}{*}{$\begin{array}{c}\text { Öğrenim } \\
\text { Düzeyi }\end{array}$} & & $\begin{array}{c}\text { Mezuniyet } \\
\text { Yok }\end{array}$ & İlköğretim & $\begin{array}{c}\text { Orta } \\
\text { Öğretim }\end{array}$ & $\begin{array}{l}\text { Yüksek } \\
\text { Okul }\end{array}$ & Lisans & $\begin{array}{c}\text { Lisans } \\
\text { Üstï }\end{array}$ & & Toplam \\
\hline & Siklık & 380 & 1279 & 492 & 120 & 248 & 37 & & 2556 \\
\hline & $\begin{array}{l}\text { Yüzde } \\
(\%)\end{array}$ & 14,9 & 50,0 & 19,2 & 4,7 & 9,7 & 1,4 & & 100 \\
\hline \multirow[b]{3}{*}{$\begin{array}{l}\text { Gelir } \\
\text { Düzeyi }\end{array}$} & & $0-2164$ & $1265-1814$ & \begin{tabular}{|l|}
$1815-2540$ \\
\end{tabular} & 2541-3721 & $3722+$ & & & Toplam \\
\hline & Siklık & 700 & 610 & 410 & 395 & 441 & & & 2556 \\
\hline & $\begin{array}{l}\text { Yüzde } \\
(\%)\end{array}$ & 27,4 & 23,9 & 16,0 & 15,5 & 17,3 & & & 100 \\
\hline \multirow{3}{*}{$\begin{array}{l}\text { İşteki } \\
\text { Durum }\end{array}$} & & Ücretli & İşveren & $\begin{array}{c}\text { Kendi } \\
\text { Hesabına } \\
\text { Çalışan } \\
\end{array}$ & $\begin{array}{l}\text { Ücretsiz } \\
\text { Aile İşçisi }\end{array}$ & Çalışmıyor & & & Toplam \\
\hline & Siklik & 1297 & 62 & 287 & 154 & 756 & & & 2556 \\
\hline & $\begin{array}{l}\text { Yüzde } \\
(\%)\end{array}$ & 50,7 & 2,4 & 11,2 & 6,0 & 29,7 & & & 100 \\
\hline \multirow{3}{*}{$\begin{array}{c}\text { Genel } \\
\text { Sağlık } \\
\text { Durumu }\end{array}$} & & Çok İyi & İyi & Orta & Kötü & Çok Kötü & & & Toplam \\
\hline & Siklık & 227 & 1419 & 676 & 195 & 39 & & & 2556 \\
\hline & $\begin{array}{l}\text { Yüzde } \\
(\%)\end{array}$ & 8,9 & 55,5 & 26,4 & 7,6 & 1,5 & & & 100 \\
\hline
\end{tabular}




\begin{tabular}{|c|c|c|c|c|c|}
\hline \multirow{3}{*}{$\begin{array}{c}\text { Yaşam } \\
\text { Faaliyet } \\
\text { Kisitlanma } \\
\text { Durumu }\end{array}$} & & $\begin{array}{c}\text { Ciddi } \\
\text { Ölçüde } \\
\text { Kısıtlandı }\end{array}$ & $\begin{array}{c}\text { Kısıtlandı } \\
\text { fakat } \\
\text { Ciddi } \\
\text { Ölçüde } \\
\text { Değil }\end{array}$ & $\begin{array}{l}\text { Kisitlan- } \\
\text { madi }\end{array}$ & Toplam \\
\hline & Siklık & 253 & 757 & 1546 & 2556 \\
\hline & $\begin{array}{l}\text { Yüzde } \\
(\%)\end{array}$ & 9,9 & 29,6 & 60,5 & 100 \\
\hline \multirow{3}{*}{$\begin{array}{c}\text { Kronik } \\
\text { Rahatszzlık }\end{array}$} & $\begin{array}{l}\text { Yüzde } \\
(\%)\end{array}$ & Evet & Hayır & & Toplam \\
\hline & Siklık & 1520 & 1036 & & 2556 \\
\hline & $\begin{array}{l}\text { Yüzde } \\
(\%)\end{array}$ & 59,5 & 40,5 & & 100 \\
\hline \multirow{3}{*}{ Cinsiyet } & & Erkek & Kadın & & Toplam \\
\hline & \begin{tabular}{|l} 
Yüzde \\
$(\%)$
\end{tabular} & 1336 & 1220 & & 2556 \\
\hline & Siklık & 52,3 & 47,7 & & 100 \\
\hline \multirow{3}{*}{$\begin{array}{l}\text { Medeni } \\
\text { Hal }\end{array}$} & & Evli & Bekâr & & Toplam \\
\hline & Siklık & 1719 & 837 & & 2556 \\
\hline & $\begin{array}{l}\text { Yüzde } \\
(\%)\end{array}$ & 67,3 & 32,7 & & 100 \\
\hline
\end{tabular}

Tablo 1'de yer alan frekans analizi sonuçları, sağlık hizmetlerinin finansmanında cepten harcama yöntemini kullananların sağllk kurumu tercih nedeni, yaş, öğrenim düzeyi, gelir düzeyi, işteki durumu, genel sağlık durumu, kronik rahatsızlığının bulunup bulunmadığı, sağlık durumu sebebiyle yaşam faaliyetlerinin kısıtlanıp kısıtlanmadığı, cinsiyet ve medeni durum gibi sosyoekonomik nitelikli göstergelerin örneklem itibariyle dağılımlarını içermektedir. Bu doğrultuda elde edilen sonuçlar aşağıdaki şekildedir.

- TÜİK tarafından oluşturulan Sağlık Durumu Hanehalkı Soru Formunda sağlık kurumu tercihinde etkili olan faktörlerin belirlenmesinde "sosyal güvence, ucuzluk, yakınlık, başka seçenek yokluğu, iyi davranılması, güvenilirlik, bekletilmeme, hizmet kalitesi, tanıdık personel bulunması, sevk edilme, tavsiye, rahatsızlığın ciddi olmaması, ilaç temini ve diğer" şeklinde on dört seçenek kullanılmıştır. Yapılan frekans analizi sonucunda cepten harcama yapanların önemli bir kısmının sağlık kurumu tercihinde etkili olan faktörlerin, sağlik kurumunun sosyal güvence kapsamında olması $(\% 37,3)$ ve söz konusu kurumun yakınlığı $(\% 23,2)$ olduğu sonucuna ulaşılmıştır. Bununla birlikte sağlık hizmeti kalitesi $(\% 9,9)$, seçenek yokluğu $(\% 8,3)$, güvenilirlik $(\% 5,9)$ ve ucuzluk $(\% 5,8)$ gibi faktörlerin de sağlık kurumu tercihi üzerinde etkili olduğu söylenebilir. Örneklem 
kapsamındakilerin küçük bir kısmı ise sağlık kurumu tercihinde tanıdık personelin bulunmamasının $(\% 2,2)$, tavsiyenin $(\% 1,9)$, rahatsızlı̆̆ın ciddi olmamasının $(\% 1,3)$, bekletilmemenin $(\% 1,7)$, iyi davranılmasının $(\% 0,9)$, sevk edilmenin $(\% 0,9)$ ve ilaç temininin $(\% 0,4)$ etkili olduğunu belirtmiştir.

- Sağlı hizmetlerini cepten harcama yoluyla karşılayanların önemli bir kısmının genel sağlık durumlarının iyi $(\% 55,5)$ ve orta $(\% 26,4)$ düzeyde olduğu görülmekle birlikte önemli bir bölümünde (\%59,5) kronik bir rahatsızlık bulunmaktadır. Ancak kronik rahatsızlık bulunmasına rağmen sağlık sorunlarının yaşam faaliyetlerini ciddi ölçüde kısıtlamadığı görülmektedir (Ciddi ölçüde yaşam faaliyeti kısıtlananların sıklığı \% 9,9). $\mathrm{Bu}$ durumun karşılaştırmalı olarak değerlendirilebilmesi amacıyla aşağıda yer alan çapraz tablo oluşturulmuştur.

Tablo 2: Kronik Rahatsızlık ile Yaşam Faaliyetinin Kısıtlanma Durumu Karşılaştırması

\begin{tabular}{|c|c|c|c|c|c|c|}
\hline & & & \multicolumn{4}{|c|}{ YAŞAM FAALIYYET KISITLANMA DURUMU } \\
\hline & & & $\begin{array}{c}\text { Ciddi } \\
\text { Ölçüde } \\
\text { Kısıtlandı }\end{array}$ & $\begin{array}{c}\text { Kısıtlandı } \\
\text { ama Ciddi } \\
\text { Ölçüde Değil }\end{array}$ & Kisitlanmadı & TOPLAM \\
\hline \multirow{6}{*}{$\begin{array}{l}\text { KRONIK } \\
\text { RAHATSIZLIK }\end{array}$} & \multirow{3}{*}{ Evet } & Adet & 247 & 692 & 581 & 1520 \\
\hline & & $\begin{array}{l}\text { Kronik } \\
\text { Rahatsizlık }\end{array}$ & $\% 16,25$ & $\% 45,53$ & $\% 38,22$ & $\% 100$ \\
\hline & & $\begin{array}{l}\text { Yaşam Faaliyet } \\
\text { Kıstlanma } \\
\text { Durumu }\end{array}$ & $\% 97,63$ & $\% 91,41$ & $\% 37,58$ & $\% 59,47$ \\
\hline & \multirow{3}{*}{ Hayır } & Adet & 6 & 65 & 965 & 1036 \\
\hline & & $\begin{array}{l}\text { Kronik } \\
\text { Rahatsizlık }\end{array}$ & $\% 0,58$ & $\% 6,27$ & $\% 93,15$ & $\% 100$ \\
\hline & & $\begin{array}{l}\text { Yaşam Faaliyet } \\
\text { Kistllanma } \\
\text { Durumu }\end{array}$ & $\% 2,37$ & $\% 8,59$ & $\% 62,42$ & $\% 40,53$ \\
\hline \multicolumn{2}{|l|}{ Toplam } & Adet & 253 & 757 & 1546 & 2556 \\
\hline \multicolumn{2}{|c|}{ Kronik Rahatsızlık } & $\% \mathbf{9 , 9 0}$ & $\% 29,62$ & $\% 60,49$ & $\% 100$ & \\
\hline \multicolumn{2}{|c|}{$\begin{array}{l}\text { Yaşam Faaliyet Kisitlanma } \\
\text { Durumu }\end{array}$} & $\% 100$ & $\% 100$ & $\% 100$ & $\% 100$ & \\
\hline
\end{tabular}


Sağlık sorunları sebebiyle yaşam faaliyetleri ciddi ölçüde kısıtlananların $(\% 97,63)$ aynı zamanda kronik rahatsızlıklarının da bulunduğu görülmektedir. Ancak kronik rahatsızlığı bulunanların içinde yaşam faaliyeti ciddi ölçüde kısıtlananların oranı düşük seviyededir $(\% 16,25)$.

- TÜİK tarafından oluşturulan Sağlık Durumu Hanehalkı Soru Formunda gelir beş düzeye ayrılmış olup bu düzeylere göre örneklemin dağılımı dengeli görünmekle birlikte yaklaşı \%51'lik kısmı en düşük iki gelir grubunda yer almaktadır (\% 27,4'lük kısmı 0-1264 TL grubunda ve \%23,9'luk kısmı 12651814 TL grubunda). Bununla birlikte örneklemin önemli bir kısmı $(\% 50,7)$ ücretli bir işte çalışırken önemli bir kısmı da $(\% 11,2)$ kendi hesabına çalışmaktadır. Örneklem kapsamındaki dikkat çekici bir diğer nokta ise her hangi bir işte çalışmayanların yoğunluğudur $(\% 29,7)$. Buradan hareketle, her hangi bir işte çalışmayanların $(\% 61,5)$ ve kendi hesabına çalışanların $(\% 58,2)$ önemli bir kısmı en düşük iki gelir grubunda yer almasının, gelir düzeyindeki frekansların en düşük iki gelir düzeyinde sıklaşması üzerinde etkili olduğu söylenebilir. Nitekim bu durum işteki durum ile gelir düzeyi karşılaştırmasını ortaya aşağıda yer alan çapraz tabloda da görülmektedir. 
Tablo 3: İşteki Durum ile Gelir Düzeyi Karşılaştırması

\begin{tabular}{|c|c|c|c|c|c|c|c|c|}
\hline & \multirow{2}{*}{$\begin{array}{l}\text { GELIR } \\
\text { GRUPLARI }\end{array}$} & \multirow{2}{*}{ DEĞİŞKEN } & \multicolumn{6}{|c|}{ GELİR DÜZEYI } \\
\hline & & & $0-1.264$ & $\begin{array}{l}1.265- \\
1.814\end{array}$ & $\begin{array}{l}1.815- \\
2.540\end{array}$ & $\begin{array}{l}2.541- \\
3.721\end{array}$ & $\begin{array}{c}3.722 \text { ve } \\
\text { üzeri }\end{array}$ & TOPLAM \\
\hline \multirow{15}{*}{$\begin{array}{l}\text { İŞTEKİ } \\
\text { DURUM }\end{array}$} & \multirow{3}{*}{ Ücretli } & Adet & & & & 241 & 291 & 1.297 \\
\hline & & $\begin{array}{l}\text { İşteki } \\
\text { Durum }\end{array}$ & 18,12 & 24,83 & 16,04 & 18,58 & 22,44 & 100 \\
\hline & & Hane-Gelir & 33,57 & 52,79 & 50,73 & 61,01 & 65,99 & 50,74 \\
\hline & \multirow{3}{*}{$\begin{array}{l}\text { İssyeri } \\
\text { Sahibi }\end{array}$} & Adet & 9 & 8 & 7 & 13 & 25 & 62 \\
\hline & & $\begin{array}{l}\text { İşteki } \\
\text { Durum }\end{array}$ & 14,52 & 12,90 & 11,29 & 20,97 & 40,32 & 100 \\
\hline & & $\begin{array}{l}\text { Hane ᄀ- } \\
\text { Gelir }\end{array}$ & 1,29 & 1,31 & 1,71 & 3,29 & 5,67 & 2,43 \\
\hline & \multirow{3}{*}{$\begin{array}{l}\text { Kendi } \\
\text { Hesabına } \\
\text { Çalışan }\end{array}$} & Adet & 92 & 75 & 53 & 33 & 34 & 287 \\
\hline & & $\begin{array}{l}\text { İşteki } \\
\text { Durum }\end{array}$ & 32,06 & 26,13 & 18,47 & 11,50 & 11,85 & 100 \\
\hline & & $\begin{array}{l}\text { Hane } า- \\
\text { Gelir }\end{array}$ & 13,14 & 12,30 & 12,93 & 8,35 & 7,71 & 11,23 \\
\hline & \multirow{3}{*}{$\begin{array}{l}\text { Ücretsiz } \\
\text { Aile İşçisi }\end{array}$} & Adet & 75 & 29 & 26 & 11 & 13 & 154 \\
\hline & & $\begin{array}{l}\text { İşteki } \\
\text { Durum }\end{array}$ & 48,70 & 18,83 & 16,88 & 7,14 & 8,44 & 100 \\
\hline & & $\begin{array}{l}\text { Hane ᄀ- } \\
\text { Gelir }\end{array}$ & 10,71 & 4,75 & 6,34 & 2,78 & 2,95 & 6,03 \\
\hline & \multirow{3}{*}{$\begin{array}{l}\text { Herhangi } \\
\text { bir İşte } \\
\text { Çalışmıyor }\end{array}$} & Adet & 289 & 176 & 116 & 97 & 78 & 756 \\
\hline & & $\begin{array}{l}\text { İşteki } \\
\text { Durum }\end{array}$ & 38,23 & 23,28 & 15,34 & 12,83 & 10,32 & 100 \\
\hline & & $\begin{array}{l}\text { Hane }- \text { - } \\
\text { Gelir }\end{array}$ & 41,29 & 28,85 & 28,29 & 24,56 & 17,69 & 29,58 \\
\hline \multirow{3}{*}{\multicolumn{2}{|c|}{ Hane ᄀ-Gelir }} & Adet & 700 & 610 & 410 & 395 & 441 & 2556 \\
\hline & & 27,39 & 23,87 & 16,04 & 15,45 & 17,25 & 100 & \\
\hline & & 100 & 100 & 100 & 100 & 100 & 100 & \\
\hline
\end{tabular}

- Sağlık hizmetlerini cepten harcama yoluyla karşılayanların önemli bir kısmının öğrenim düzeyi ilköğretim (\%50) ve orta öğretim $(\% 19,2)$ seviyesinde olmakla birlikte herhangi bir okul tamamlamamış olanların da oldukça yüksek düzeyde $(\% 14,9)$ olduğu görülmektedir. Buradan hareketle sağlık hizmetlerinden cepten harcama yoluyla yararlananların büyük ölçüde öğrenim seviyesi düşük insanlar olduğu söylenebilir.

- Yaş, cinsiyet ve medeni hal değişkenlerine bakıldığında ise örneklemin önemli bir kısmının 25-55 yaş aralığında olduğu (yaklaşık \%61), erkek ve 
kadın dağılımı yakın olmakla birlikte erkeklerin biraz daha fazla olduğu $(\% 52,3)$, evli olanların $(\% 67,3)$ bekârlara $(\% 32,7)$ göre önemli ölçüde yüksek olduğu görülmektedir.

\section{Lojistik Regresyon Analizi Sonuçları}

Bu bölümde, SPSS 16 programı aracılığıyla işlenen veriler kullanılarak en az değişken ile en iyi uyuma sahip olacak bir modelin kurulmasına imkân veren lojistik regresyon analizi sonuçları yer almaktadır. Analiz kapsamında öncelikle modelin uygunluğu, model katsayılarının anlamlılığı ve modelin uyum iyiliğine yönelik testler yapılmış, sonrasında oluşturulması amaçlanan modelin tahmin sonuçlarına yer verilmiştir.

\section{Modelin Uygunluğu}

Modelin uygunluğu, modelde yer alan bağımsız değişkenler arasında ilişki bulunması halinde ortaya çıkan çoklu doğrusal bağlantının bulunmamasını gerektirmektedir. Bu doğrultuda yapılan analiz sonuçları aşağıda yer alan tabloda özetlenmiştir. 
Tablo 4: Çoklu Doğrusal Bağlantı Analizi

\begin{tabular}{|c|c|c|c|c|c|c|c|c|c|c|c|c|}
\hline & \multicolumn{2}{|c|}{$\begin{array}{c}\text { Standardize } \\
\text { Olmayan } \\
\text { Katsaylar }\end{array}$} & \multirow{2}{*}{\begin{tabular}{|c}
$\begin{array}{c}\text { Standardize } \\
\text { Katsayılar }\end{array}$ \\
Beta
\end{tabular}} & \multirow[t]{2}{*}{$\mathrm{t}$} & \multirow[t]{2}{*}{ Anlamlılık } & \multicolumn{2}{|c|}{$\begin{array}{c}95,0 \% \text { Güven } \\
\text { Aralığı }\end{array}$} & \multicolumn{3}{|c|}{ Korelasyonlar } & \multicolumn{2}{|c|}{$\begin{array}{c}\text { Doğrusal } \\
\text { Bağlantı } \\
\text { İstatistikleri }\end{array}$} \\
\hline & B & $\begin{array}{l}\text { Std. } \\
\text { Hata }\end{array}$ & & & & Alt & Üst & Pearson & Kismi & $\begin{array}{c}\text { Yar1 } \\
\text { K1smi }\end{array}$ & Tolerans & VIF \\
\hline (Sabit) & 1,426 & 0,596 & & 2,394 & 0,017 & 0,258 & 2,595 & & & & & \\
\hline $\begin{array}{l}\text { Hane Gelir } \\
\text { Düzeyi }\end{array}$ & $-0,112$ & 0,006 & $-0,331$ & $-17,761$ & 0 & $-0,125$ & $-0,1$ & $-0,423$ & $-0,333$ & $-0,29$ & 0,767 & 1,304 \\
\hline $\begin{array}{l}\text { Genel Sağlık } \\
\text { Durumu }\end{array}$ & 0,071 & 0,014 & 0,118 & 5,148 & 0 & 0,044 & 0,098 & 0,063 & 0,102 & 0,084 & 0,511 & 1,956 \\
\hline $\begin{array}{l}\text { Kronik } \\
\text { Rahatsızlık } \\
\text { Varlığ1 }\end{array}$ & 0,053 & 0,02 & 0,053 & 2,635 & 0,008 & 0,014 & 0,092 & 0,073 & 0,052 & 0,043 & 0,658 & 1,521 \\
\hline $\begin{array}{l}\text { Yasam } \\
\text { Faaliyeti } \\
\text { Kisitlanma } \\
\text { Durumu }\end{array}$ & 0,03 & 0,017 & 0,041 & 1,793 & 0,073 & $-0,003$ & 0,063 & 0,019 & 0,036 & 0,029 & 0,515 & 1,943 \\
\hline Cinsiyet & $-0,042$ & 0,017 & $-0,043$ & $-2,549$ & 0,011 & $-0,075$ & $-0,01$ & $-0,008$ & $-0,051$ & $-0,042$ & 0,938 & 1,066 \\
\hline Yaş & $-0,069$ & 0,006 & $-0,235$ & $-12,262$ & 0 & $-0,08$ & $-0,058$ & $-0,211$ & $-0,237$ & $-0,2$ & 0,726 & 1,377 \\
\hline $\begin{array}{l}\text { Medeni } \\
\text { Durum }\end{array}$ & 0,047 & 0,018 & 0,045 & 2,674 & 0,008 & 0,013 & 0,082 & 0,083 & 0,053 & 0,044 & 0,935 & 1,069 \\
\hline $\begin{array}{l}\text { Öğretim } \\
\text { Düzeyi }\end{array}$ & $-0,054$ & 0,008 & $-0,13$ & $-6,53$ & 0 & $-0,07$ & $-0,038$ & $-0,245$ & $-0,129$ & $-0,107$ & 0,671 & 1,489 \\
\hline $\begin{array}{l}\text { Özel Sağlık } \\
\text { Sigortası } \\
\text { Sahipliği }\end{array}$ & 0,017 & 0,042 & 0,007 & 0,412 & 0,68 & $-0,065$ & 0,1 & 0,099 & 0,008 & 0,007 & 0,932 & 1,072 \\
\hline $\begin{array}{l}\text { Sosyal } \\
\text { Güvence }\end{array}$ & 0,19 & 0,021 & 0,187 & 8,943 & 0 & 0,148 & 0,231 & 0,212 & 0,175 & 0,146 & 0,609 & 1,641 \\
\hline Ucuzluk & $-0,206$ & 0,038 & $-0,098$ & $-5,493$ & 0 & $-0,28$ & $-0,133$ & $-0,195$ & $-0,108$ & $-0,09$ & 0,838 & 1,193 \\
\hline $\begin{array}{l}\text { Seçenek } \\
\text { Yokluğu }\end{array}$ & $-0,156$ & 0,033 & $-0,088$ & $-4,765$ & 0 & $-0,22$ & $-0,092$ & $-0,194$ & $-0,094$ & $-0,078$ & 0,79 & 1,267 \\
\hline $\begin{array}{l}\text { Hizmet } \\
\text { Kalitesi }\end{array}$ & 0,015 & 0,03 & 0,009 & 0,507 & 0,612 & $-0,044$ & 0,075 & $-0,015$ & 0,01 & 0,008 & 0,775 & 1,291 \\
\hline \begin{tabular}{|l|} 
Iyi \\
Davranılması \\
\end{tabular} & $-0,075$ & 0,084 & $-0,015$ & $-0,893$ & 0,372 & $-0,241$ & 0,09 & $-0,036$ & $-0,018$ & $-0,015$ & 0,968 & 1,033 \\
\hline Güvenilirlik & 0,091 & 0,037 & 0,044 & 2,438 & 0,015 & 0,018 & 0,164 & 0,065 & 0,048 & 0,04 & 0,837 & 1,194 \\
\hline Bekletilmeme & 0,144 & 0,064 & 0,038 & 2,26 & 0,024 & 0,019 & 0,268 & 0,065 & 0,045 & 0,037 & 0,939 & 1,065 \\
\hline \begin{tabular}{l|l} 
Tanıdık \\
Personel \\
Bulunması
\end{tabular} & 0,059 & 0,057 & 0,018 & 1,04 & 0,298 & $-0,052$ & 0,17 & 0,048 & 0,021 & 0,017 & 0,92 & 1,086 \\
\hline Sevk Edilme & $-0,036$ & 0,088 & $-0,007$ & $-0,407$ & 0,684 & $-0,208$ & 0,137 & $-0,027$ & $-0,008$ & $-0,007$ & 0,97 & 1,031 \\
\hline Tavsiye & 0,178 & 0,06 & 0,05 & 2,956 & 0,003 & 0,06 & 0,296 & 0,039 & 0,059 & 0,048 & 0,941 & 1,063 \\
\hline $\begin{array}{l}\text { Rahatsılı̆̆ı̆ } \\
\text { Ciddi } \\
\text { Olmaması }\end{array}$ & $-0,044$ & 0,073 & $-0,01$ & $-0,607$ & 0,544 & $-0,186$ & 0,098 & $-0,048$ & $-0,012$ & $-0,01$ & 0,954 & 1,048 \\
\hline İlaç Temini & 0,017 & 0,13 & 0,002 & 0,128 & 0,898 & $-0,238$ & 0,271 & 0,026 & 0,003 & 0,002 & 0,975 & 1,025 \\
\hline
\end{tabular}

Değişkenlerinin tolerans değerleri (tolerans değerleri $>0,1$ ) ve varyans artış değerlerine $(\mathrm{VIF}<10)$ bakıldığında çoklu doğrusal bağlantının bulunmadığı görülmektedir³.

\footnotetext{
${ }^{3}$ Bununla birlikte değişkenlerin özdeğerleri (özdeğerler benzerlik göstermektedir), durum indeksleri (durum indeksleri benzerlik göstermektedir) ve varyans oranları (değişkenlerin en yüksek varyansı farklı özdeğerlere yüklenmiştir) incelenerek de çoklu doğrusal bağlantının olmadığı teyid edilmiştir.
} 


\section{Model Katsayılarının Anlamlılığı}

Model katsayıların anlamlılığı her bir adım için ki-kare istatistiğinin hesaplandığı omnibüs testi ile yapılmaktadır. Bu test ile "sadece sabit terimin yer aldığı başlangıç modeli ile bağımsız değişkenlerin analize girmesiyle oluşan sonuç modeli arasında fark yoktur" şeklindeki boş hipotez sınanmaktadır. Yapılan sınama sonucunda model katsayıların anlamlı kabul edilebilmesi için boş hipotezin reddi, dolayısıyla da bağımsız değişkenler ile bağımlı değişken arasındaki ilişkinin desteklenmesi gereklidir. Bu doğrultuda yapılan analiz sonuçları aşağıda yer alan tabloda özetlenmiştir.

Tablo 5: Omnibus Testi

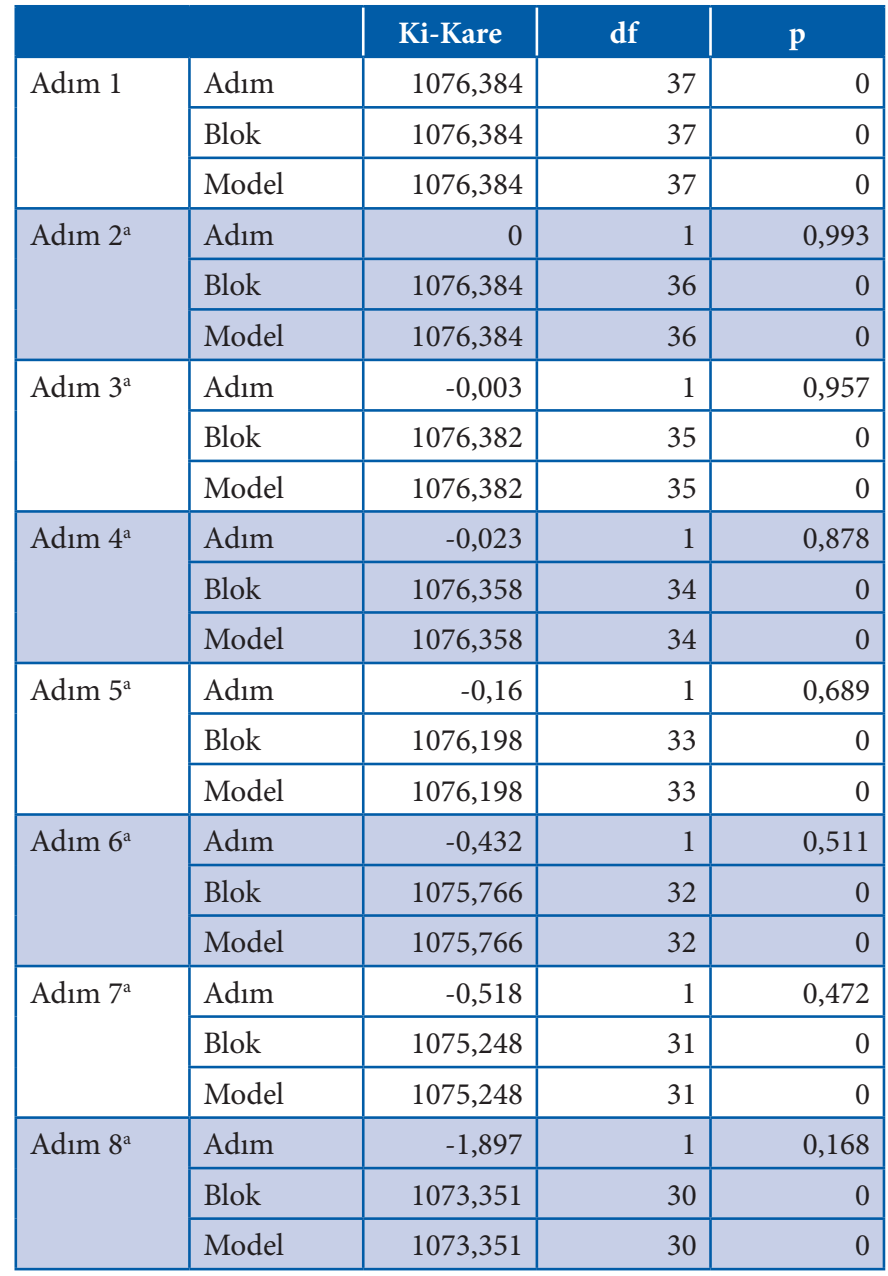


Model ki-kare değişkenine ilişkin $\mathrm{p}$ değeri anlamlıdır $(\mathrm{p}<0,05)$. Boş hipotez reddedilmiş ve bağımsız değişkenler ile bağımlı değişken arasındaki ilişkinin varlığ 1 kabul edilmiştir. Buna bağlı olarak model katsayılarının da anlamlı olduğu sonucuna ulaşılmıştır.

\section{Modelin Uyum İyiliği}

Modelin uyum iyiliği, değişkenler arasındaki ilişkinin derecesini gösteren amaçlanan model özeti ve lojistik regresyon modelinin bütün olarak uyumunu inceleyen Hosmer ve Lemeshow uyum iyiliği testi ile değerlendirilecektir.

Tablo 6: Amaçlanan Modelin Özeti

\begin{tabular}{|l|c|c|c|}
\hline Adım & $\begin{array}{c}-\mathbf{2} \text { Log } \\
\text { likelihood }\end{array}$ & Cox \& Snell & Nagelkerke \\
\hline 1 & $2366,949 \mathrm{a}$ & 0,344 & 0,464 \\
\hline 2 & $2366,949 \mathrm{a}$ & 0,344 & 0,464 \\
\hline 3 & $2366,952 \mathrm{a}$ & 0,344 & 0,464 \\
\hline 4 & $2366,976 \mathrm{a}$ & 0,344 & 0,464 \\
\hline 5 & $2367,135 \mathrm{a}$ & 0,344 & 0,464 \\
\hline 6 & $2367,567 \mathrm{a}$ & 0,344 & 0,464 \\
\hline 7 & $2368,086 \mathrm{a}$ & 0,343 & 0,464 \\
\hline 8 & $2369,982 \mathrm{a}$ & 0,343 & 0,463 \\
\hline
\end{tabular}

Modeldeki bütün bağımsız değişkenler analize dâhil edildiğinde, bağımlı değişkendeki varyansın Cox \& Snell değeri olarak \% 34,3 ve Nagelkerke değeri olarak da \% 46,3’lük kısmını açıklamaktadır. Bununla birlikte her iki test de klasik regresyon analizlerindeki değeri ile benzerlik göstermekle birlikte, farklı olarak değerler küçük çıkmaktadır. Buna bağlı olarak da klasik regresyondan farklı olarak bu testlerde 0,20-0,40 arasındaki bir değer yüksek olarak kabul edilmektedir (Şenel ve Alatlı, 2014, s. 41). Ayrıca Nagelkerke değeri standardize edilmiş olduğu için Cox \& Snell değerine göre daha çok dikkate alınmaktadır (Rençber, 2018, s. 107). 
Tablo 7: Hosmer ve Lemeshow Test Sonuçları

\begin{tabular}{|l|c|c|c|}
\hline Adım & Ki-Kare & df & $\mathbf{p}$ \\
\hline 1 & 11,73 & 8 & 0,164 \\
\hline 2 & 11,728 & 8 & 0,164 \\
\hline 3 & 11,214 & 8 & 0,19 \\
\hline 4 & 11,16 & 8 & 0,193 \\
\hline 5 & 11,498 & 8 & 0,175 \\
\hline 6 & 12,638 & 8 & 0,125 \\
\hline 7 & 11,708 & 8 & 0,165 \\
\hline 8 & 11,967 & 8 & 0,153 \\
\hline
\end{tabular}

Bütün adımlarda Hosmer ve Lemeshow testinin sonucu anlamlı çıkmamaktadır ( $p>0,05)$. Testin anlamlı olmaması çok değişkenli modelin kabul edilebilir bir uyuma sahip olduğunu ve model ile veri arasındaki uyumun yeterli düzeyde olduğunu göstermektedir.

\section{Amaçlanan Modelin Değerlendirilmesi}

Oluşturulan modelin analiz aşamasında her bir değişkenin ilk kategorisi referans kategori olarak belirlenmiştir. Bu doğrultuda oluşturulan lojistik regresyon modelinin sonuçları aşağıdaki şekildedir. 
Tablo 8: Amaçlanan Model Değişkenlerinin Tahmin Sonuçları

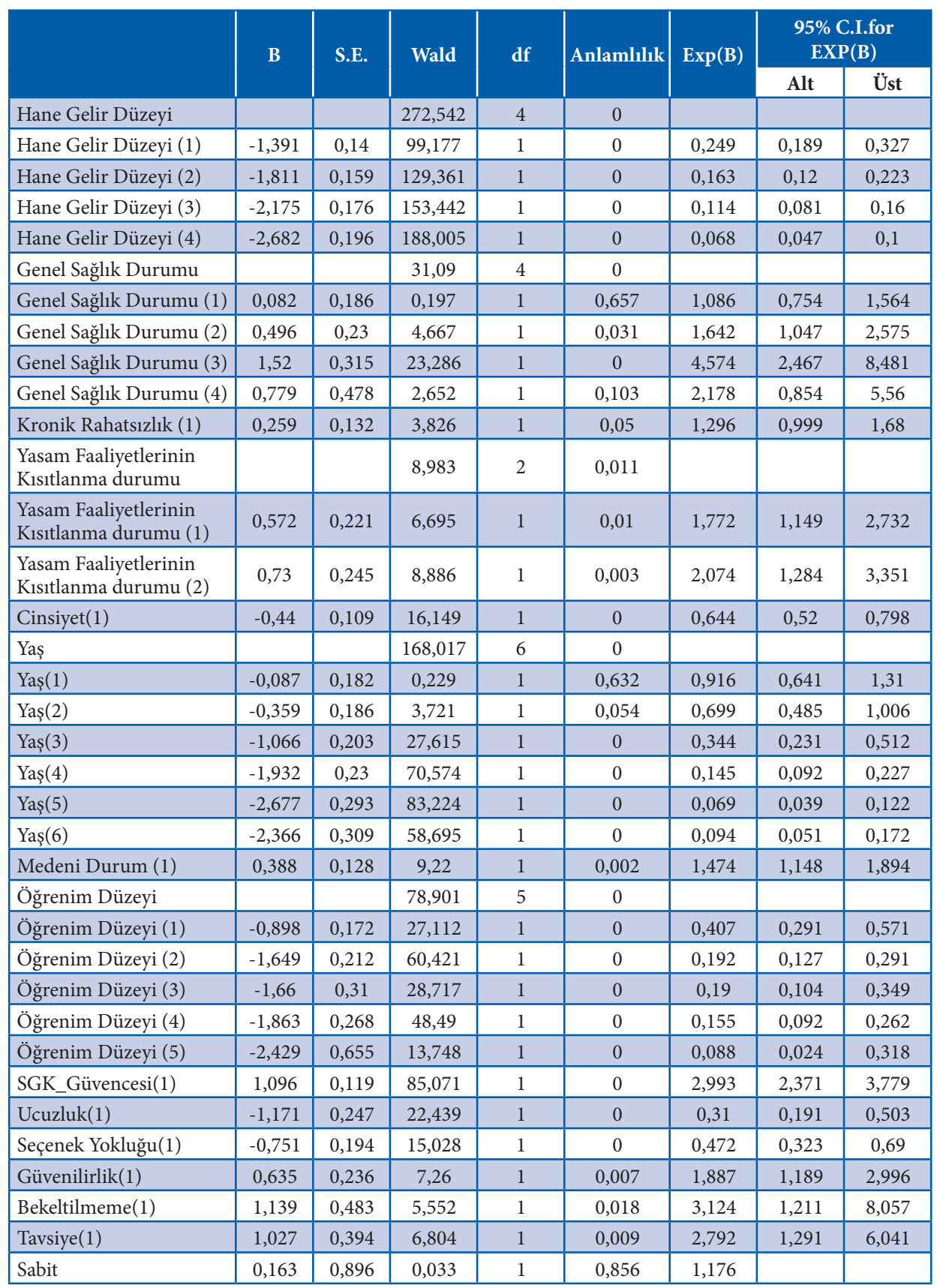


Modelin analizinde kullanılan kodlamalar ve referans kategoriler göz önünde bulundurulduğunda amaçlanan modelin tahmin sonuçları aşağıdaki şekilde değerlendirilmektedir.

- 0-1.264 TL gelir düzeyine göre 1.265-1.814 TL gelir grubunda olanlar için 0,249 kat; 1.815-2.540 TL gelir grubunda olanlar için 0,163 kat, 2.541-3.721 gelir grubunda olanlar için 0,114 kat ve 3.722 ve daha üzeri gelir grubunda olanlar için 0,068 kat cepten harcama yapılmama olasılı̆̆ 1 daha fazladır. Dolayısıyla gelir düzeyi yükseldikçe cepten sağlık harcaması yapma olasılığ da artmaktadır.

- Genel sağlık durumu çok iyi olanlara göre iyi olanlar için 1,086 kat; orta olanlar için 1,642 kat; kötü olanlar için 4,574 kat ve çok kötü olanlar için 2,178 kat cepten harcama yapılmama olasılığı daha fazladır. Dolayısıyla genel sağlık durumu iyileştikçe cepten sağlık harcaması yapma olasılı̆̆1 artmaktadir.

- Kronik rahatsızlığı olmayanların olanlara göre cepten harcama yapmama olasılığı 1,296 kat daha fazladır. Dolayısıyla kronik rahatsızlığın bulunması halinde cepten sağlık harcaması yapılma olasılığı artmaktadır.

- Sağlık sorunları sebebiyle yaşam faaliyetleri ciddi ölçüde kısıtlananlara göre ciddi ölçüde kısıtlanmayanların 1,772 kat; kısıtlanmayanların ise 2,074 kat cepten harcama yapmama olasılı̆̆ daha fazladır. Dolayısıyla yaşam faaliyetlerinin kısıtlılık düzeyi arttıkça cepten sağlık harcaması yapma olasılığ 1 artmaktadır.

- Kadınların erkeklere göre cepten harcama yapmama olasılığı 0,644 kat daha fazladır. Dolayısıyla kadınların cepten sağlık harcaması yapma olasılığı daha yüksektir.

- 15-24 yaş grubuna göre 25-34 yaş grubu için 0,916 kat; 35-44 yaş grubu için 0,699 kat; 45-54 yaş grubu için 0,344 kat; 55-64 yaş grubu için 0,145 kat; 65-74 yaş grubu için 0,069 kat ve 75 üzeri yaş grubu için 0,094 kat cepten harcama yapılmama olasılığı daha fazladır. Dolayısıyla yaş grubu yükseldikçe cepten sağlık harcaması yapma olasılığı artmaktadır.

- Bekârların evlilere göre cepten harcama yapmama olasillğ 1 1,474 kat daha fazladır. Dolayısıyla evlilerde cepten sağlık harcaması yapılma olasılığı 
daha yüksektir. Hiçbir okul tamamlamamış olanlara göre ilköğretim mezunlarının 0,407 kat; ortaöğretim mezunlarının 0,192 kat; yüksek okul mezunlarının 0,190 kat; lisans mezunlarının 0,155 kat; yüksek lisans mezunlarının 0,088 kat cepten harcama yapmama olasılığı daha fazladır. Dolayısıyla öğrenim düzeyi yükseldikçe cepten sağlık harcaması yapma olasılığı artmaktadır.

- Sağlik kurumu tercihinde sosyal güvenliğe önem vermeyenlerin verenlere göre 2,993 kat; ucuzluğa önem vermeyenlerin verenlere göre 0,310 kat; başka seçenek yokluğunun tercih sebebi olmayanların olanlara göre 0,472 kat; güvenilirliğe önem vermeyenlerin verenlere göre 1,887 kat; bekletilmemeye önem vermeyenlerin verenlere göre 3,124 kat; tavsiyeye önem vermeyenlerin verenlere göre 2,792 kat cepten harcama yapmama olasılığı daha fazladır. Dolayısıyla sağlı kurumu tercihinde sosyal güvenlik, güvenilirlik, bekletilmeme ve tavsiyeye önem verenlerde cepten sağlık harcaması yapma olasılığı daha yüksektir.

Amaçlanan model değişkenleri bütün olarak değerlendirildiğinde genel olarak gelir düzeyi, öğrenim düzeyi, yaş yükseldikçe; özel nitelikler itibariyle de kronik rahatsızlığın bulunması halinde, kadınlarda, evlilerde cepten sağlık harcaması yapma olasılığının arttığı sonucuna ulaşılmıştır.

Halihazırda cepten harcama yapanların sosyal güvenlik sistemi kapsamına dâhil olması halinde dahi cepten harcama yapma olasılığına ilişkin elde edilen bu sonuçlar, literatürde doğrudan doğruya cepten harcama yapma olasılığına ilişkin elde edilen sonuçlar ile benzerlik göstermekte olup; özellikle Türkiye için yapılan çalışmalarda elde edilen sonuçlar ile tamamen uyumludur. Literatürde yer alan çalışmalarda kullanılan veri setleri farklılık göstermekle birlikte iki farklı durum üzerinde belirleyici olan faktörlerin aynı olması (sosyal güvenlik kapsamında olunsa da olunmasa da cepten harcama olasılığının yüksek gelir gruplarında artması ve diğer faktörler); Türkiye'de cepten harcamaların katastrofik etkiye yol açtı̆̆ 1 dolayısıyla da özellikle düşük gelir gruplarında cepten harcama yapılmasını gerektiren durumlarda sağlık hizmeti talebinin ortaya çıkmadığ 1 ya da çıkamadığı sonucuna yöneltmektedir. Bu sonuçlardan hareketle, sağlık hizmetlerinin içerik ve türüne ilişkin bir verinin ya da karşılaştırmanın içerilmiyor olmasının da etkisiyle, cepten ödemelerin fiyat farklılaşmasına bağlı olarak ortaya çıktığı söylenebilir. 
Diğer taraftan literatürde elde edilen sonuçlardan önemli bir farklılık, sağlık kurumu tercih nedeni hususunda ortaya çıkmıştır. Sağlık kurumu tercihinde etkili olan faktörlere ilişkin TÜİK tarafından hazırlanan anket formunda yer alan 14 farklı seçenekten 6 tanesi model kapsamında belirleyici faktörler olarak yer almıştır. Bu faktörlerden de sosyal güvenlik kapsamında olma, sağlık kurumuna güven, bekletilmeme ve tavsiyenin cepten harcama yapma olasılığını artırması, bir taraftan cepten harcamaların sosyal güvencenin varlığı halinde yapılabildiği dolayısıyla da katastrofik etkinin ortaya çıkma olasılığındaki azalmaya, bir taraftan da sağlık hizmetinin içeriğindeki farklılığa yönelik inanca (tavsiye, güven) bağlı olduğu söylenebilir. Sosyal güvencenin olması, dolayısıyla da katastrofik etkinin ortaya çıkma olasılığının azalması halinde hizmet içeriğine verilen önemin cepten ödeme konusunda etkili olduğu görülmektedir. Bu sonuçlardan hareketle de, cepten ödemelerin hizmet farklılaşmasına bağlı olarak ortaya çıktığı söylenebilir.

$\mathrm{Bu}$ çerçevede cepten ödemelerin, fiyat farklılaşmasına bağlı ortaya çıkması, literatürde ile uyumluluk gösteren değişkenler bağlamında gerçekleşirken; literatürden farklı olarak sağlık kurum tercihinde etkili olan faktörlerin de sorgulanması halinde cepten ödemeler üzerinde hizmet farklılaşmasının da etkili olduğu sonucuna ulaşılmıştır.

\section{Sonuç}

Sağlık, Birleşmiş Milletler İnsan Hakları Yüksek Komiseri, Mary Robinson tarafından "Sağlık hakkı sağlıklı olma hakkı demek değildir; yoksul ülkelerin kaynakları olmadığı halde pahalı sağlık servisleri kurmaları demek de değildir. Sağlık hakkı, hükümetlerin ve yöneticilerin mümkün olan en kısa zamanda herkesin ulaşabileceği ve yararlanabileceği bir sağllk sistemini kuracak politikalar ve eylem planları ortaya koymalarını gerektirir. Bunun gerçekleşmesini güvence altına almak, hem insan haklarıyla uğraşanların hem de halk sağlığı çalışanlarının vermeleri gereken en büyük mücadeledir" şeklinde ele alınmaktadır (Dünya Sağlık Örgütü, 2002).

Sağlık hizmetlerinin cepten ödemeler yoluyla karşılanması ise, sağlığın, insan olma halinin bir gerekliliği, toplumsal niteliği, devlet ve devlet üstü bağlama sahip niteliği nedeniyle, gerek DSÖ tarafından gerekse ülkeler ölçeğinde politika belirleyicileri tarafından finansal güvence anlamında 
çözülmesi gereken bir problem niteliğindedir. Ancak oluşturulan politikaların sadece cepten ödemeler yoluyla ortaya çıkacak katastrofik etkilerin azaltılmasına yönelik dolayısıyla da fiyat farklılaşması temelinde değil; cepten ödemelerin sağlık hizmet sunumunda hizmet farklılaşmasına dayanan yapısının da önlenmesine yönelik olması gereklidir. Aksi takdirde cepten ödemelerin azaltılması ya da telafi edilmesine yönelik politikalar, sağlık hizmet sunumunun içeriği ve niteliği göz ardı edilerek, sadece harcama kalemlerindeki bir düzenleme olarak kalacaktır.

$\mathrm{Bu}$ çalışma kapsamında da cepten ödemelerin sağlık hizmetlerindeki fiyat farklılaşmasına mı yoksa hizmet farklılaşmasına bağlı olarak gerçekleştiğinin ortaya konulması amaçlanmıştır. $\mathrm{Bu}$ amaç doğrultusunda hali hazırda literatürde kabul gören fiyat farklılaşmasının ötesinde, hizmet farklılaşmasının da etkisi olup olmadığını ortaya koyabilmek için doğrudan doğruya cepten ödemeler değil; sosyal güvenlik kapsamındayken dahi cepten ödemelerin yapılma olasılığı incelenmiştir. Yapılan analizler sonucunda gelir düzeyi yükseldikçe, kronik rahatsızlığı bulunmakla birlikte genel sağlık durumu iyi olanlar ile yaşam faaliyetlerini kısıtlayıcı ölçüde sağlık sorunu bulunanlarda, kadınlarda, evlilerde, yaş grubu yükseldikçe, öğrenim düzeyi yükseldikçe ve sağlık kurumu tercihinde zorunluluk dışı faktörlere önem verenlerde sosyal güvenlik kapsamındayken cepten ödeme yapma olasılığının daha yüksek olduğu sonucuna ulaşılmıştır. Bu sonuçlar, cepten ödemelere yönelik literatürde elde edilen sonuçlar ile uyumluluk göstermekle birlikte; sağlık kurumu tercih nedenlerinin de sosyal güvenlik kapsamındayken dahi cepten ödeme yapılması üzerinde belirleyici olduğunun ortaya konulması ile literatürdeki çalışmalardan farklılık gösterilmiştir. Ulaşılan bu sonuç beraberinde, fiyat farklılaşmasının ötesinde hizmetin türü ve içeriğine ilişkin hizmet farklılaşmasının da cepten ödemeler üzerinde belirleyici olduğu sonucunu getirmiştir.

Cepten ödemelerin beraberinde fiyat farklılaşmasını getirmesi, ödeme gücünün bulunulması halinde cepten ödeme yöntemi ile sağlık hizmet sunumunun tercih edilmesi ya da ödeme gücünün bulunulmamasına bağlı olarak katastrofik etkinin oluşumu sağlık hizmetinin kamu ya da özel mal olarak sunumu açısından olağan bir durumdur. Ancak cepten ödemelerin 
hizmet farklılaşmasına bağlı olarak ortaya çıkması, sağlık hizmetlerinin özel mal ve kamu malı ayrımındaki fiyat farklılaşmasının ötesinde kamu malı olarak sunumundaki problemlerin varlığına işaret etmektedir. Bu durum bir takım sağlık hizmetlerinin sadece özel mal olarak sunulduğu anlamına gelebileceği gibi, bu çalışma kapsamında elde edilen bulgular bağlamında sağlık hizmetlerinin özel mal olarak sunumun daha nitelikli olduğu; dolayısıyla da sağlık hizmetinin kamu malı olarak talebi yerine cepten ödeme yapılarak daha nitelikli olduğu düşünülen özel mal şeklinde talep edildiği söylenebilir.

$\mathrm{Bu}$ çerçevede genel olarak sağlık hizmetleri, spesifik olarak da cepten ödemelere yönelik yapılacak uygulama ve düzenlemelerde sağlık hizmetleri sunumunda kamu ve özel mal ikiliğinin fiyat farklılaşması ile sınırlı kalacak şekilde niteliksel farklılıkların ortadan kaldırılmasını esas alması gereklidir. Buna bağlı olarak da cepten ödemelerin, nitelikli sağlık hizmeti kaygısıyla, sadece ödeme gücü bulunanlar tarafından ya da ödeme gücü bulunmayanlarda katastrofik etkiye maruz kalınarak gerçekleştirilmesinin önemi de göz ardı edilmemelidir. 


\section{Kaynakça}

Atasoy, D. (2001). Lojistik Regresyon Analizinin Incelenmesi ve Bir Uygulaması. Sivas: Cumhuriyet Üniversitesi Sosyal Bilimler Enstitüsü.

Attia-Konan, A. R., Oga, A. S., Toure, A., Kouadio, K. L. (2019). Distribution of Out of Pocket Health Expenditures in a Sub-Saharan Africa Country: Evidence from the National Survey of Household Satandard of Living, Cote d'Ivoire. BMC Research Notes, 12-25.

Başara, B. B., Şahin, İ. (2008). Türkiye'de Cepten Yapılan Sağlık Harcamalarını Etkileyen Etmenler. Hacettepe Üniversitesi İktisadi ve İdari Bilimler Fakültesi Dergisi, 26(2), 319-340.

Bernabe, E., Masood, M., Vujicic, M. (2017). The Impact of Out-of-Pocket Payment for Dental Care on Household Finances in Low and Middle Income Countries. BMC Public Health.

Bose, M., Dutta, A. (2018). Health Financing Strategies to Reduce Out of Pocket Burden in India: A Comparative Study of Three States. BMC Health Serices Research, 1-10.

Brinda, E. M., Andres, R. A., Enemark, U. (2014). Correlates Out-of-Pocket and Catastrophic Health Expenditures in Tanzania: Results from a National Household Survey. BMC International Health \& Human Rights, 14(5).

Çınaroğlu, S. (2018). Cepten Sağlık Harcamalarının Finansmanında Eşitsizlik ve Hakkaniyet: Uygulamalı Bir Ekonometrik Yaklaşım. İşletme Araştırmaları Dergisi, 876-897.

Çokluk, Ö. (2010). Lojistik Regresyon Analizi: Kavram ve Uygulama. Kuram ve Uygulamada Eğitim Bilimleri, 10(3), 1357-1407.

Dünya Sağlık Örgütü. (2018). https://www.who.int/health_financing/topics/financial-protection/out-of-pocket-payments/en/ (Erişim: 30.01.2019).

Erus, B., Aktakke, N. (2012). Impact of Healthcare Reforms on Out-of-Pocket Health Expenditures in Turkey For Public Insurees. The European Journal of Health Economics, 337-346.

Field, A. (2005). Discovering Statistics Using SPSS (Cilt 2). London: Sage Publications.

Garson, G. D. (2012). Testing Statistical Assumptions. USA:Statistical Associates Publishing. 
Goldman, D. P., Zissimopoulos, J. M. (2003). High Out-of-Pocket Health Care Spending By the Elderly. Data Watch, 194-202.

Hwang, W., Weller, W., Ireyes, H., \& Anderson, G. (2001). Out-of-Pocket Medical Spending for Care of Chronic Conditions. Health Affairs, 267-278.

Laokri, S., Soelaeman, R., Hotchkiss, D. R. (2018). Assessing Out-of Pocket Expenditures for Primary Health Care: How Responsie is the Democratic Republic of Congo Health System to Providng Financ,al Risk Protection? BMC Health Services Research, $1-19$.

Lara, J. L. (2016). Catastrophic EXpenditure Due to Out-of-Pocket Health Paymnets and its Determinants in Colombian Households. International Journal for Equity in Health, 15(182).

Mamun, S. A., Khanam, R., Rahman, M. M. (2018). The Determinants of Household Out-of-Pocket (OOP) Medical Expenditure in Rural Bangladesh. Applied Health Economics and Health Policy, 16, 219-234.

Mugisha, F., Kouyate, B., Gbangou, A., Sauerborn, R. (2002). Examining Out-of-Pocket Expenditure on Health Care in Nouna, Burkino Faso: Implications for Health Policy. Tropical Medicine and International Health, 187-196.

Organization, W. H. (2007). Sağlık ve İnsan Hakları Üzerine 25 Soru 25 Cevap. Toplum Sağlığı Araştırma ve Geliştirme Merkezi Derneği. https://apps.who.int/iris/bitstream/handle/10665/42526/9241545690_tur.pdf;jsessionid=84F99739E1780499D4EB37F35E97863B ?sequence $=10$ adresinden alınd 1

Paez, K. A., Zhao, L.,Hwang, W. (2009). Rising Out-of-Pocket Spending for Chronic Conditions: A Ten-Year Trend. Health Affairs, 28(1), 15-25.

Rençber, Ö. F. (2018). Sinıflandırma Problemlerinde Çoklu Lojistik Regresyon, Yapay Sinir Ağı ve ANFIS Yöntemlerinin Karşılaştırılması: İnsani Gelişmişlik Endeksi Üzerine Uygulama. Ankara: Gazi Kitabevi.

Rubio, R. d., Salido, R. M., Garcia, I. P., Sotos, F. E. (2019). Catastrophic Long-Term Care Expenditure: Associated Socio-Demographic and Economic Factors. The European Journal of Health Economics.

Sangar, S., Dutt, V., Thakur, R. (2019). Coping with Out-of-Pocket Health Expendiure in India: Evidence from NSS 71st Round. Global Social Welfare. 
Sanwald, A., Theurl, E. (2015). Out-of-Pocket Payments in the Austrian Healthcare System -A Distributional Analysis. International Journal for Equity in Health, 14(94).

Sanwald, A., Theurl, E. (2016). Out-of-Pocket Expenditure by Priate Householdsfor Denthal Services-Empirical Evidence from Austria. Health Economics Review, 6-10.

Sene, L. M., Cisse, M. (2015). Catastrophic Out-of-Pocket Payments for Health and Poverty Nexus: Evidence from Senegal. International Journal of Health Economics and Management, 15, 307-328.

Şenel, S., Alatlı, B. (2014). Lojistik Regresyon Analizinin Kullanıldığı Makaleler Üzerine Bir İnceleme. Eğitimde ve Psikolojide Ölçme ve Değerlendirme Dergisi, 5(1), 35-52.

Tokatlığlu, Y., \& Tokatlığlu, İ. (2018). Türkiyede Katastrofik Sağlık Harcamaları ve Bu Harcamaları Belirleyen Faktörler. Sosyoekonomi, 26(35), 59-78.

Türkiye İstatistik Kurumu.(2018). Sağlık Harcamaları İstatistikleri Haber Bülteni. https:// www.tuseb.gov.tr/enstitu/tacese/yuklemeler/RAPORLAR/tuik_2018_saglik_harcamalari_2017.pdf. (Erişim: 31.01.2019).

Yardım, M. S., Çilingiroğlu, N., \& Yardım, N. (2010). Catastrophic Health Expenditure and Impoverishment in Turkey. Health Policy, 94, 26-33.

Yereli, A. B., Köktaş, A. M., Selçuk, I. Ş. (2014). Türkiye’de Katastrofik Sağlık Harcamalarını Etkileyen Faktörler. Sosyoekonomi, 273-296.

Yildırım, J., Yılmaz, E., Korucu, N. (2011). The Determinants of Out-of-Pocket Payments: Evidence from Selected Hospitals in Ankara, Turkey. Applied Economics Letters, 1159-1162.

You, X., Kobayashi, Y. (2011). Determinants of Out-of-Pocket Health Expenditure in China: Analysis Using China Health and Nutrition Surey Data. Applied Health Economics and Health Policy, 9(1), 39-49. 